Toxicol Appl Pharmacol. 2020 December 01; 408: 115256. doi:10.1016/j.taap.2020.115256.

\title{
Biological effects of inhaled hydraulic fracturing sand dust. VIII.
}

Stacey E. Anderson , Hillary Shane, Carrie Long, Antonella Marrocco, Ewa Lukomska, Abstract \begin{abstract}
of a FSD, i.e., FSD 8, was investigated at 1, 7, and $27 \mathrm{~d}$ post-exposure in rats. Exposure to 10 contrast, increases in LLN cellularity and increases in total CD4+ and CD8+ T-cells were observed Co alveolar lavage fluid at 7-d post-exposure phenotypic subsets, and impairment of immune function.
\end{abstract}

\footnotetext{
*Corresponding author at: Allergy and Clinical Immunology Branch, National Institute for Occupational Safety and Health, 1000 Frederick Lane, Morgantown, WV 26508, United States of America., sanderson4@cdc.gov (S.E. Anderson). Credit author statement

Stacey Anderson: primary author, experimental design, tissue collection, immune suppression assay, data analyses.

Hillary Shane, contributing author, experimental design, tissue collection, flow cytometry, data analyses.

Carrie Long: tissue collection and processing, analysis of serum chemistries and complete blood counts.

Antonella Marracco: tissue collection and processing, analysis of serum chemistries and complete blood counts.

Ewa Lukomska: natural killer cell assays.

Jenny Roberts: animal necropsy, BAL, blood, serum, spleen and LN collection.

Nikki Marshall: contributing author, flow cytometry, data analyses.

Jeffrey S. Fedan: conceptualization of the experiments and experimental design.

Supplementary data to this article can be found online at https://doi.org/10.1016/j.taap.2020.115256.

Declaration of Competing Interest

The authors declare that they have no known competing financial interests or personal relationships that could have appeared to influence the work reported in this paper.
} 


\section{Keywords}

Fracking sand dust; Immunotoxicity; Immunosuppression; Fracking; Immune phenotyping

\section{Introduction}

This is the eighth in a series of tandem papers in which the potential toxicity of a fracking sand dust (FSD), i.e., FSD 8, has been comprehensively investigated. Its focus is on an examination of the effects of inhalation exposure to FSD 8 on the immune system of rats. The reader is directed to the first paper in the series (Fedan, 2020), which describes the overall approach to the investigation in the context of current knowledge about silica. The other studies in this series have concerned the effects of FSD 8 on lung ventilatory and nonventilatory functions, inflammatory mechanisms, and cardiovascular, and immune systems, brain and blood (Russ et al., 2020; Sager et al., 2020; Krajnak et al., 2020; Sriram et al., 2020) as well as cytotoxicity (Olgun et al., 2020), and been summarized (Fedan et al., 2020). Hydraulic fracturing (i.e., "fracking") involves high pressure injection of large volumes of water and sand, along with smaller quantities of chemicals, into a gas or oil well to fracture shale or other rock formations, allowing more efficient recovery of hydrocarbons (Esswein et al., 2013). A review of the fracking process is described by Fedan et al. (2020). While fracking presents numerous environmental and health concerns, airborne dust generated during fracking (i.e., fracking sand dust), has recently been identified as an occupational exposure concern. While various types, sizes, colors, and treatments of sand are used during fracking operations, standards and specifications have been established (API, 1995). A major component of all FSD is crystalline silica (Mossman and Glenn, 2013). Silica is most widely distributed in dusts and sands as various forms of silicon dioxide (silica) or silicates.

Crystalline silica occurs naturally in rock and sand, and in commercial products such as concrete, ceramics, bricks, and tiles. Exposure to respirable crystalline silica occurs most often in occupational settings, where materials containing crystalline silica are reduced to dust or when fine particles are disturbed. Esswein et al. (2013) measured exposures to crystalline silica at gas well drilling sites and found that the personal breathing zone samples of dust collected at wells in six geographical areas indicated that exposures to silica exceeded the full-shift exposure limits recommended by the Occupational Safety and Health Administration (OSHA), the National Institute for Occupational Safety of Health (NIOSH), and the American Conference of Governmental Industrial Hygienists (ACGIH). In addition to fracking, applications and occupations with a high risk for silica exposure include: foundries, brick making, painting, glass, concrete, china, pottery, plumbing, construction, silica sand blasting, and coal mining (Cohen et al., 2008).

Significant effects of crystalline silica on the immune system have been reported and are thought to be a result of its potential adjuvancy. At airborne levels exceeding current occupational standards in the workplace, silica exposure has been associated with the development of silicosis, silicotuberculosis, cancer, and autoimmune disorders (Sayan and Mossman, 2016). Lung injury typically occurs when inhaled silica particles reach the alveoli and are ingested by alveolar macrophages. The direct cytotoxic effects of silica result in 
macrophage death with a subsequent inflammatory cascade resulting in fibrosis (Pollard, 2016). In addition, the increasing extracellular presence of various autoantigens such as DNA, RNA, and other organelles released from apoptotic macrophages following silica particle phagocytosis may increase the likelihood for activation of the immune system (Maeda et al., 2010).

While studies investigating the immunotoxicity of crystalline silica have been widely reported, investigations into the immune-related effects of inhaled FSD are lacking. Therefore, the present study was undertaken to evaluate immunotoxicity in rats following whole-body inhalation exposure of FSD 8 obtained from a domestic gas well fracking site. The antibody response to sheep red blood cells (SRBC), immune cell phenotyping, and natural killer (NK) cell activity were selected as endpoints for the evaluation of FSD 8 induced immunotoxicity.

\section{Methods}

\subsection{Animals}

These studies were conducted in facilities accredited by AAALAC International, were approved by the institutional Animal Care and Use Committee (14-JF-R-004) and were in compliance with the Public Health Service Policy on Humane Care and Use of Laboratory Animals and the NRC Guide for the Care and Use of Laboratory Animals. Male SpragueDawley rats ([H1a: (SD) CVF, approximate body weight of 200-250 $\mathrm{g}$ at arrival, were obtained from Hilltop Lab Animals, Inc. (Scottdale, PA). All animals were free of viral pathogens, parasites, mycoplasm, Heliobacter, and cilia-associated respiratory bacillus. Animals were acclimated for 1 wk., housed in pairs in ventilated microisolator units supplied with HEPA-filtered laminar flow air (Thoren Caging Systems; Hazleton, PA), with 7090 Sani Chip and 7070C Diamond Dry combination (both from Harlan, now Envigo; Indianapolis, IN) for bedding, and provided tap water and 2918 irradiated Teklad Global $18 \%$ rodent diet (Harlan, now Envigo; Indianapolis, IN) ad libitum.

Rats were housed under controlled light cycle (12 h light/12 h dark) and temperature (22-25 $\left.{ }^{\circ} \mathrm{C}\right)$ conditions.

\subsection{FSD 8 inhalation exposures and general protocol}

The FSD used in this study was FSD 8, one of nine FSDs that were collected at domestic fracking operations and compared against respiratory crystalline silica (MIN-U-SIL $® 5$; MIN-U-SIL) with regard to chemical and physical properties and preliminary toxicity appraisal (Fedan et al., 2020). A more detained characterization of FSD 8 and the wholebody inhalation exposure system is described in accompanying reports (Fedan et al., 2020; McKinney et al., 2013; Russ et al., 2020). The concentrations selected for use in these studies were based off of previous studies conducted at NIOSH and determined to be comparable to human exposure (Russ et al., 2020).

Rats ( 8 per group) were exposed by whole body inhalation to filtered air or 10 or $30 \mathrm{mg} / \mathrm{m}^{3}$ FSD 8 for $6 \mathrm{~h} / \mathrm{d}$ for $4 \mathrm{~d}$. Experimental end points were examined at 1, 7, and $27 \mathrm{~d}$ postexposure for each concentration of FSD 8. Two exposure studies (Table 1) were utilized to 
obtain the immunotoxicity data presented in this report. For the first exposure study (A), NK cell activity, immune cell phenotyping, serum chemistries, and complete blood counts were evaluated. The data presented for the second study (B) was restricted to the IgM response to SRBC due to immunization.

\subsection{Tissue processing}

On days 1, 7, and 27 following the last exposure to FSD 8 or filtered air, rats were given an i.p. injection of sodium pentobarbital (100-300 mg/kg; Fatal Plus; Vortech Pharmaceuticals; Dearborn, MI). Following exsanguination, the trachea was cannulated, the chest cavity was opened, the right bronchus was clamped off, and bronchoalveolar lavage (BAL) fluid was collected from the left lung. The first lavage sample was obtained by filling the right lung with $1 \mathrm{ml} / 100 \mathrm{~g}$ of phosphate-buffered saline (PBS), massaging for $30 \mathrm{~s}$, withdrawing, and repeating the process one more time. This concentrated aliquot was withdrawn, retained, kept separately, and was designated as the first fraction of BAL fluid. The following aliquots were $6 \mathrm{ml}$ in volume, instilled once with light massaging, withdrawn, and combined until a $30 \mathrm{ml}$ volume was obtained. For each animal, both lavage fractions were centrifuged (10 min, $598 \times g$ ), and the cell pellets were combined and re-suspended in $1 \mathrm{ml}$ of PBS. The spleen and lung associated lymph nodes (LLN) were removed, cleaned of connective tissue placed in complete medium (CM)[(RPMI-1640, 10\% fetal bovine serum (FBS; HyClone, Waltham, MA) and $100 \mathrm{IU}$ penicillin/100 $\mu \mathrm{g}$ streptomycin (Sigma-Aldrich; St. Louis, MO) per ml of medium] or sterile PBS, respectively. LLN were prepared by mechanical disruption of tissues between frosted microscope slides in PBS. Spleens were prepared using a $30 \mathrm{ml}$ syringe plunger and subsequently passing the homogenate through a cell strainer. To identify the total number of cells, $20 \mu \mathrm{l}$ of cells was added to $10 \mathrm{ml}$ of Isoton II diluent (1:500; Beckman Coulter; Brea, CA) and two drops of ZAP-OGLOBIN (Beckman Coulter) were added to lyse red blood cells. Cells were then counted using a Coulter counter.

\subsection{Flow cytometry}

Cells $\left(1-2 \times 10^{6}\right)$ were dispensed into a 96-well u-bottom plate and washed in staining buffer (PBS $+1 \%$ bovine serum albumin $+0.1 \%$ sodium azide). Cells were re-suspended in staining buffer containing anti-rat CD32 antibody (clone D34-485) for blocking of Fc receptor (BD Biosciences; San Jose, CA). Cells were next resuspended in staining buffer containing a cocktail of biotin and fluorochrome-conjugated mouse anti-rat antibodies specific for cell surface antigens: CD3-FITC (clone G4.18), CD4-APC (OX-35), CD8aPerCP (OX-8), CD11b-V450 (WT.5), CD45RA-PE (OX-33) and CD161a-Biotin (10/78) (BD Biosciences). Cells were washed with staining buffer and re-suspended in staining buffer containing streptavidin APC-Cy7 secondary (BD Biosciences). Following an incubation, cells were washed twice in staining buffer and fixed in Cytofix buffer according to the manufacturer's instructions (BD Biosciences). Within $24 \mathrm{~h}$, cells were re-suspended in staining buffer and analyzed on an LSR II flow cytometer (BD Biosciences). Data analysis was performed with FlowJo 7.6.5 software (TreeStar Inc.; Fenton, MI). Cells gated on single cells using SSC-A $\times$ SSC-H doublet discrimination were identified as CD4 T cells (CD4+ CD3+), CD8 T cells (CD8+ CD3+), B cells (CD45RA+ CD3-), NK cells (CD161ahi CD3-), and $\mathrm{CD} 11 \mathrm{~b}+$ myeloid cells. 


\subsection{Natural killer cell assay}

NK cell activity was evaluated using Yac-1, murine lymphoma cell line (ATCC; Manassas, VA), as the target cell. Target cells were cultured in complete media maintained at $37^{\circ} \mathrm{C}$ in a humidified, $5 \% \mathrm{CO}_{2}$ atmosphere, and monitored daily. Cells were harvested in the log phase of growth, washed with Dulbecco's PBS, and counted using 0.4\% trypan blue solution. Only the cultures with greater than $95 \%$ cell viability were selected for use in the assay. Target cells were labeled with carboxyfluorescein succinmidyl ester (CellTrace ${ }^{\mathrm{TM}}$ CFSE Proliferation Kit; Life Technologies; Waltham, MA) according to the manufacturer's directions. Cells were pelleted, washed twice in CM to wash off the unbound dye, counted in $0.4 \%$ trypan blue solution and diluted to the desired concentration in CM. Splenocytes (effector cells) collected and processed as described above were also used for the NK cell assay. The cytotoxicity assay was performed in 96-well, round bottom, tissue culture-treated microtiter plates. Effector cells were seeded in a $100 \mu \mathrm{l}$ volume/well with a fixed number of CFSE-stained target cells (20,000/well) with effector to target ratios ranging from 50:1 to 150:1. Control wells for spontaneous death of target contained CFSE-stained target with no effectors (0:1, E:T ratio). Effectors only, unstained target, CFSE-stained target and Live/ Dead Fixable Violet Dead Cell (Invitrogen; Waltham, MA)-stained target were also included as assay controls. Recombinant rat IL-2 (0.05 ng/ $\mu \mathrm{l}$; R\&D Systems; Minneapolis, MN) was added to all wells for enhancement of baseline cytotoxic activity. The contents of each well was mixed gently by pipetting, centrifuged briefly at $526 \times g$, and incubated at $37{ }^{\circ} \mathrm{C}$ in a humidified $5 \% \mathrm{CO}_{2}$ atmosphere for $4 \mathrm{~h}$. Killing was stopped by placing the plate on ice for 5 min. Samples were subsequently stained with Live/Dead Fixable Violet Dead Cell Stain and fixed in Cytofix fixation buffer (BD Bioscience) according to the manufacturer's directions. Stained samples were analyzed on LSR II flow cytometer (BD Biosciences). The results were expressed as percentage of dead targets on a cell-to-cell basis.

\subsection{Hematology and serum chemistries}

Following administration of an overdose of sodium pentobarbital and exsanguination, whole blood was collected from the abdominal aorta of the rats used for Study A. A $150 \mu$ laliquot was used for hematology, and $0.5 \mathrm{ml}$ serum (collected from $5 \mathrm{ml}$ of centrifuged blood) was used for serum chemistry analysis. Selected serum chemistries were evaluated using a Catalyst DX Chemistry Analyzer (IDEXX Laboratories, Inc.; Westbrook, ME). End points analyzed included: albumin (ALB), globulin (GLOB), alkaline phosphates (ALKP), alanine aminotransferase (ALT), urea nitrogen (BUN), creatinine (CREA), glucose (GLU), total protein (TP), creatine kinase (CK), triglycerides (TRICL), cholesterol (CHOL), ALB/GLOB ratio, and BUN/CREA ratio. Selected hematological parameters were evaluated using a ProCyte DX Automatic Hematology Analyzer (IDEXX). Endpoints analyzed included peripheral erythrocyte and leukocyte counts, leukocyte differentials (lymphocytes, neutrophils, monocytes, basophils, and eosinophils), reticulocytes, platelet counts, hematocrit, hemoglobin levels, mean corpuscular hemoglobin $(\mathrm{MCH})$ and hemoglobin concentration (MCHC), mean corpuscular volume (MCV), mean platelet volume (MPV), platelet hematocrit (PCT), and platelet distribution width (PDW). 


\subsection{Spleen IgM response to SRBC}

For study B, the primary IgM response to SRBC was enumerated using a modified hemolytic plaque assay of Jerne and Nordin (Jerne and Nordin, 1963; Marrocco et al., 2015). Four days prior to euthanasia, the rats were immunized with $2 \times 10^{8} \mathrm{SRBC}$ (in $1 \mathrm{ml}$ volume) by i.v. injection. All SRBC for these studies were drawn from a single donor animal (Lampire Laboratories; Pipersville, PA). On days 1, 7, and 27 following the last exposure to FSD 8 or air, rats were euthanized by $\mathrm{CO}_{2}$ asphyxiation, body and spleen weights were recorded, and spleens were collected in $10 \mathrm{ml}$ of Hank's balanced salt solution (HBSS). Blood was also retrieved in serum collection tubes following transection of the abdominal aorta and stored at $-20^{\circ} \mathrm{C}$ for subsequent analysis of serum anti-SRBC IgM levels (see below).

Single cell suspensions of the spleens from individual animals were prepared in HBSS by disruption using a $30 \mathrm{ml}$ syringe plunger and subsequent passage through a cell strainer to filter cellular debris. To identify the total number of spleen cells, $20 \mu \mathrm{l}$ of cells was added to $10 \mathrm{ml}$ of Isoton II diluent (1:500; Beckman Coulter) and two drops of ZAP-OGLOBIN (Beckman Coulter) were added to lyse red blood cells. Cells were then counted using a Coulter counter. Dilutions (1:60 and 1:120) of spleen cells were then prepared and $100 \mu \mathrm{l}$ of each dilution were added to test tubes containing a $0.5 \mathrm{ml}$ warm agar/dextran mixture $(0.5 \%$ Bacto-Agar; Thermo Scientific, Waltham, MA) and 0.05\% DEAE dextran (Sigma-Aldrich), $25 \mu \mathrm{l}$ of 1:1 ratio of SRBC suspension, and $25 \mu \mathrm{l}$ of 1:4 dilution (1 ml lyophilized) guinea pig complement (Cedarlane Laboratories; Burlington, Ontario). Each sample was vortexed, poured into a petri dish, covered with a microscope coverslip, and incubated for $3 \mathrm{~h}$ at $37^{\circ} \mathrm{C}$. The plaques (representing antibody-forming B-cells) were then counted. Results were expressed in terms of both specific activity (IgM PFC per $10^{6}$ spleen cells) and total activity (IgM PFC per spleen).

\subsection{Serum IgM response to SRBC}

Serum samples were analyzed for anti-SRBC IgM using a commercially available ELISA kit (Life Diagnostics, Inc.; West Chester, PA), according to the manufacturer's recommendations with modifications. Test serum was diluted (1:200, 1:400, 1:800, and 1:1600) and incubated in the microtiter wells for $45 \mathrm{~min}$ at $25^{\circ} \mathrm{C}$. The wells were subsequently washed, $100 \mu \mathrm{l}$ horseradish peroxidase-conjugated secondary antibody was added, and the plates were incubated for a further $45 \mathrm{~min}$ at $25^{\circ} \mathrm{C}$. Thereafter, the wells were washed to remove unbound antibodies and $100 \mu$ letramethyl-benzidine peroxidase (TMB) reagent was added to each well. The plates were then incubated for $20 \mathrm{~min}$ at room temperature before color development was stopped by the addition of $50 \mu \mathrm{l}$ kit-provided stop solution. Optical density in each well was then measured spectrophotometrically at $450 \mathrm{~nm}$ using a Spectra Max M2 plate reader (Molecular Devices; Sunnyvale, CA). The concentration of the anti-SRBC IgM in the test samples was determined by comparison to a standard curve generated in parallel using SoftMax Pro software (Molecular Devices) and reported as units of anti-SRBC $\operatorname{IgM}(\mathrm{U} / \mathrm{ml})$ plotted vs. absorbance values at $450 \mathrm{~nm}$. 


\subsection{Statistical analyses}

To determine statistically significant differences in immunological endpoints, a 2-tailed unpaired $t$-test was used to compare rats exposed to filtered air or FSD 8 at the specified time point. Presented data are based on the means \pm SEM of 8 rats for each treatment group at each time point, except for the NK cell assay, in which 4 rats per exposure group were used. The results are expressed as means \pm SEM. Differences between control and experimental groups were accepted as significant when $P<0.05$ or $P<0.01$. Statistical analysis was performed using Graph Pad Prism version 5.0 (San Diego, CA).

\section{Results}

\subsection{Immunophenotyping}

The immune cell subsets present in LLN, BAL, and spleen along with total cellularity were characterized using flow cytometry at each of the post-exposure time points. Following exposure to $10 \mathrm{mg} / \mathrm{m}^{3} \mathrm{FSD} 8$, a statistically significant decrease in LLN cellularity was observed at $7 \mathrm{~d}$ post-exposure (Table 2). Exposure to $10 \mathrm{mg} / \mathrm{m}^{3} \mathrm{FSD} 8$ resulted in decreased number of total B-cells, CD4+ T-cells, CD8+ T-cells and total NK cells at $7 \mathrm{~d}$ post-exposure. The frequency of CD4+ T-cells was also decreased, while the frequency of B-cells increased at 7 and $27 \mathrm{~d}$ post-exposure in the LLN. Significant increases in LLN lymph node cellularity along with increases in total CD4+ and CD8+ T-cells were observed in rats following exposure to $30 \mathrm{mg} / \mathrm{m}^{3}$ FSD 8 but only at $1 \mathrm{~d}$ post-exposure (Table 3 ). While no change in total cellularity of the BAL fluid was observed, significant increases in the frequency and number of CD4+ T-cells and NK cells were observed at $7 \mathrm{~d}$ post-exposure $\left(10 \mathrm{mg} / \mathrm{m}^{3}\right)$ along with a significant increase in total CD4+ T-cells, CD11b + cells, and NK cells at $1 \mathrm{~d}$ postexposure $\left(30 \mathrm{mg} / \mathrm{m}^{3}\right)$ (Tables 4 and 5). Also, in the absence of changes in cellularity, significant increases in the number of B-cells and CD8+ T-cells were observed in the spleen but only at 1 day post $30 \mathrm{mg} / \mathrm{m}^{3} \mathrm{FSD} 8$ exposure (Supplementary Tables 1 and 2).

\subsection{Natural killer cell assay}

Exposure to FSD 8 suppressed NK cell function at $1 \mathrm{~d}\left(30 \mathrm{mg} / \mathrm{m}^{3}\right)$ and $27 \mathrm{~d}$ post-exposure $\left(10 \mathrm{mg} / \mathrm{m}^{3}\right)$ (Fig. 1). A significant decrease in the percent killing was observed at one effector to target ratio (1:150) at $1 \mathrm{~d}$ post-exposure (Fig. 1B) and at both effector to target ratios (1:50 and 1:150) at $27 \mathrm{~d}$ post-exposure. With nearly a $20 \%$ decrease in killing activity observed (Fig. 1E). No significant changes in percent killing were observed at either effector to target ratios following exposure to $30 \mathrm{mg} / \mathrm{m}^{3} \mathrm{FSD} 8$ at $27 \mathrm{~d}$ post-exposure. Additionally, no changes were observed at $7 \mathrm{~d}$ post-exposure for either concentration (Fig. $1 \mathrm{C}$ and D).

\subsection{Hematology and serum chemistries}

No significant changes in serum chemistries or hematology were identified in any of the post-exposure time points following $10 \mathrm{mg} / \mathrm{m}^{3}$ (data not shown) or $30 \mathrm{mg} / \mathrm{m}^{3}$ FSD 8 exposure (Supplementary Tables 3 and 4). 


\subsection{IgM response to SRBC}

The IgM response to SRBC was examined following inhalation exposure to FSD 8 to evaluate whether exposure to FSD 8 was immunosuppressive. No significant reductions in the $\mathrm{PFC} /$ spleen or specific ( $\mathrm{PFC} / 10^{6}$ cells) IgM antibody activity against SRBC were observed after exposure to $10 \mathrm{mg} / \mathrm{m}^{3}$ (Fig. 2) or $30 \mathrm{mg} / \mathrm{m}^{3}$ (Fig. 3) FSD 8 at any of the postexposure time points. No changes in the serum IgM response to SRBC was observed following 10 or $30 \mathrm{mg} / \mathrm{m}^{3} \mathrm{FSD} 8$ exposure for any of the time points analyzed (Fig. S1).

\section{Discussion}

The results of the present investigation identify quantitative changes in LLN cellularity and subsets, BAL and spleen cell subsets, and potential impairment of cell function as indicated by suppression of NK cell function following whole body inhalation exposure to FSD 8 . Exposure to $10 \mathrm{mg} / \mathrm{m}^{3} \mathrm{FSD} 8$ resulted in phenotypic changes in the both the LLN and BAL along with decreases in LLN cellularity. The most significant changes occurred at the $7 \mathrm{~d}$ post-exposure time point, with select parameters including decreases in CD4+ T-cell frequency along with increases in B-cell frequency, persisting until the 27-d time point. Phenotypic analysis of LLN also revealed changes in the number of total cells and T-cell subsets (CD4+ and CD8+) following $30 \mathrm{mg} / \mathrm{m}^{3} \mathrm{FSD} 8$ exposure. Interestingly, unlike exposure to the lower concentration, significant increases were observed. Although significant increases in total cellularity were not observed in the BAL at either concentration, increases in the percent and number of CD4+ T-cells were observed at the $7 \mathrm{~d}$ post-exposure time point $\left(10 \mathrm{mg} / \mathrm{m}^{3}\right)$ and in the number of CD4+ T-cells at the $1 \mathrm{~d}$ postexposure time point $\left(30 \mathrm{mg} / \mathrm{m}^{3}\right)$. However, all phenotypic changes following exposure to 30 $\mathrm{mg} / \mathrm{m}^{3} \mathrm{FSD} 8$ were limited to the $1 \mathrm{~d}$ post-exposure time point and returned to baseline values by $7 \mathrm{~d}$ post-exposure.

It is generally well-recognized that exposure to crystalline silica results in chronic inflammation which can ultimately result in diseases such as silicosis (Pollard, 2016). However, unlike the findings presented in the current study, in animal models of pulmonary exposure to crystalline silica persistent increases in cell numbers, which are indicative of chronic inflammation, are observed. For example, following acute intranasal (1 mg) exposure of mice to crystalline silica, Beamer et al. (2010) reported significant increases in lung interstitial leukocytes at 7, 14, 21, and $28 \mathrm{~d}$ post-exposure. Silica pathogenicity occurs after the particles are engulfed by alveolar macrophages, which attempt to digest or clear the particles out of the lung. The macrophages become activated and eventually, through the induction of pro-inflammatory mediators, cell death pathways are initiated (Sayan and Mossman, 2016). These pathways lead to the release of internalized silica particles, which are encountered by adjacent phagocytic cells, thus initiating a cycle of persistent inflammation and injury at high overload concentrations. However, inflammation and repair may occur at lower exposure concentrations as a result of total clearance. While this is one potential explanation for the findings in the current study, the higher FSD 8 concentration resulted in non-persistent changes, which included increased cellularity and immune subsets compared to the lower concentration, which resulted in decreased cell populations. As reported by Fedan et al. (2020), characterization of the FSD 8 used in these studies identified 
a heterogeneous dust that was predominantly crystalline silica but also containing many other elements. This supports the concept that non-silica constituents may have influenced clearance efficiency of the FSD 8, resulting in increased inflammation after exposure to the higher FSD 8 dose, along with more direct immunological effects at the lower concentration, as evidenced by the persistence in the B and T-cell populations in the LLN.

During industrial processing of quartz, interactions occur between quartz and other minerals, present in sediments, and these may be unique depending on the location from which they were extracted. The elemental composition of the FSD 8 used in the present study (Fedan et al., 2020) was determined to be variable and particle dependent. Detectable amounts of aluminum, potassium, iron, manganese, magnesium, calcium, sulfur, and cobalt, thought to be present on the surface of the particles, were identified in addition to silicon and oxygen. Enhancement and inhibition of quartz toxicity has been demonstrated to be influenced by the association of other minerals or elements on the surface (Fubini et al., 2004; Ghiazza et al., 2011 , 2013). For example, if the quartz particles were associated with aluminum, iron, and/or carbon, toxicological effects have been reported to be blunted (Fubini et al., 2004; Ghiazza et al., 2011, 2013). However, it has also been suggested that the presence of aluminum and iron on these less inflammogenic quartzes may potentially change the surface properties of the particles, thus making them more or less toxic, respectively. Numerous studies have also found that silica particles of different sizes can induce variable immunological responses (Donaldson et al., 2001; Kim et al., 2014; Nishijima et al., 2017). The FSD evaluated in the present study was an airborne dust to which workers were exposed and was collected from a single gas well fracking site. In this mixture, the size of the particles was characterized between $0.5 \mu \mathrm{m}-10 \mu \mathrm{m}$ with the majority of particles falling between $0.5 \mu \mathrm{m}-1 \mu \mathrm{m}$ in size, and nanosized particles also were present.

Interestingly, while the phenotyping findings did not persist for all the recovery time points and varied (except for CD4+ T-cells in the BAL) depending on the FSD 8 concentration, the suppression of NK cell function was observed following exposure to both concentrations of FSD 8. A significant decrease in function was observed at the $27 \mathrm{~d}$ recovery time points following exposure to $10 \mathrm{mg} / \mathrm{m}^{3} \mathrm{FSD}$ 8. In addition, a significant reduction in $\mathrm{NK}$ cell function was observed at the $1 \mathrm{~d}$ post-exposure time point following exposure to $30 \mathrm{mg} / \mathrm{m}^{3}$ FSD 8 . These changes occurred in the absence of any NK cell-specific phenotypic changes in the spleen, suggesting that a functional immune defect had arisen. However, changes in NK cell number and frequency were observed in some of the other organs following exposure to $10 \mathrm{mg} / \mathrm{m}^{3}$ (LALN) and $30 \mathrm{mg} / \mathrm{m}^{3}$ (BAL). NK cells can act as a bridge between innate and adaptive immune responses. They play an important role in providing surveillance against neoplastic cells and as a first line of defense against viruses (Herberman and Ortaldo, 1981). Exposure to toxicants has been shown to alter NK cell activity, and evaluation of this end point has been determined to be important in assessing potential immunotoxicity. In addition to silica, the FSD 8 used in the present studies was also identified to contain several heavy metals (Fedan et al., 2020). In general, heavy metals are known immunotoxicants and many induce immunosuppression (Luster and Rosenthal, 1993). Occupational exposure to heavy metals has also been well described and associated with lung cancer (Moitra et al., 2015). In a study examining inhaled particulate matter, transition metals including iron and manganese were associated with suppressed immune 
function (Zelikoff et al., 2002). In addition, exposure of mice to environmental dust containing metals including iron, cobalt, manganese, and aluminum was reported to suppress splenic NK cell function (DeWitt et al., 2016). While in the present study NK cell function was only suppressed at $1 \mathrm{~d}$ and $27 \mathrm{~d}$ post-exposure, it is possible that this is a result of the multiple element components in the FSD 8, leading to different mechanisms of suppression. While not directly evaluated in these studies, it is plausible to propose that exposure to a soluble portion of the metals within the FSD 8 (Olgun et al., 2020; Russ et al., 2020) might be directly responsible for the immediate suppression while indirect factors associated with cell death and proinflammatory pathways initiated as a result of the pulmonary clearance of silica might be responsible for the delayed suppression.

While the suppressive properties of FSD 8 on the innate immune system were suggested by the results of the NK cell assay, these findings were not corroborated when the humoral immune response was evaluated using the IgM response to SRBC. The T-cell dependent antibody response is one of the most sensitive indicators of immune integrity because it relies on an organized immune response that is dependent on the functional capacity and cooperation of numerous cell types, including B-cells, T-cells, and macrophages (Anderson et al., 2006). Immunosuppression determined by the spleen IgM response to SRBC was not observed after exposure to FSD 8 in the spleen or serum. Evaluation of the predictability and sensitivity of assays to evaluate immunotoxicity has previously identified a strong concordance between a reduced plaque forming cell response, cell surface marker analysis (more specifically CD4+/CD8+ cells ratio), and NK cell function (Luster and Rosenthal, 1993). While a reduction in NK cell function was observed in the present study, increases in CD8+ cell numbers were observed only at the 1-day time point in the spleens following exposure to $30 \mathrm{mg} / \mathrm{m}^{3}$. In addition, systemic effects of FSD 8 were not observed following analysis of serum chemistries and CBCs.

In summary, short-term whole-body inhalation exposure to FSD 8 resulted in early increases in lymphocyte populations $\left(30 \mathrm{mg} / \mathrm{m}^{3}\right)$, and localized suppression $\left(10 \mathrm{mg} / \mathrm{m}^{3}\right)$ along with a potential functional impairment of innate immunity in rats. The suspected health effects of FSD 8 because it contains silica, coupled to the risks of worker exposures, clearly demonstrates the need for additional studies evaluating the potential adverse human health effects caused by exposure to FSD 8 and other FSDs.

\section{Supplementary Material}

Refer to Web version on PubMed Central for supplementary material.

\section{Acknowledgements}

Funding was provided by the National Institute for Occupational Safety and Health, Project Number 7927ZLDC.

Disclaimer

The findings and conclusions in this report are those of the author(s) and do not necessarily represent the official position of the National Institute for Occupational Safety and Health, Centers for Disease Control and Prevention. Mention of brand name does not constitute product endorsement. 


\section{References}

American Petroleum Institute, 1995 API RP 56, Recommended Practices for Testing Sand Used in Hydraulic Fracturing Operations. Washington, D.C.

Anderson SE, Munson AE, Meade BJ, 2006 Analysis of immunotoxicity by enumeration of antibodyproducing B cells In: Bus JS, Costa LG, Hodgson E, Lawrence DA, Reed D (Eds.), Current Protocols in Toxicology. Hoboken, New Jersey.

Beamer CA, Migliaccio CT, Jessop F, Trapkus M, Yuan D, Holian A, 2010 Innate immune processes are sufficient for driving silicosis in mice. J. Leukoc. Biol 88, 547-557. [PubMed: 20576854]

Cohen RA, Patel A, Green FH, 2008 Lung disease caused by exposure to coal mine and silica dust. Sem. Respir Crit. Care Med 29, 651-661.

DeWitt J, Buck B, Goossens D, Hu Q, Chow R, David W, Young S, Teng Y, Leetham-Spencer M, Murphy L, Pollard J, McLaurin B, Gerads R, Keil D, 2016 Health effects following subacute exposure to geogenic dusts from arsenic-rich sediment at the Nellis dunes recreation area, Las Vegas, NV. Toxicol. Appl. Pharmacol 304, 79-89. [PubMed: 27221630]

Donaldson K, Stone V, Duffin R, Clouter A, Schins R, Borm P, 2001 The quartz hazard: effects of surface and matrix on inflammogenic activity. J. Environ. Pathol. Toxicol. Oncol 20 (Suppl. 1), $109-118$.

Esswein EJ, Breitenstein M, Snawder J, Kiefer M, Sieber WK, 2013 Occupational exposures to respirable crystalline silica during hydraulic fracturing. J. Occup. Environ. Hyg 10, 347-356. [PubMed: 23679563]

Fedan JS, 2020 Biological effects of inhaled hydraulic fracturing sand dust. I. Scope of the investigation. Toxicol. Appl. Pharmacol (Manuscript submitted to this journal as a tandem paper to accompany this manuscript.).

Fedan JS, Hubbs AF, Barger M, Schwegler-Berry D, Friend S, Leonard SS, Thompson JA, Jackson MC, Snawder JE, M. C, Dozier AK, Coyle J, Kashon ML, Park J-H, McKinney W, Roberts JR, 2020 Biological effects of inhaled hydraulic fracturing sand dust. II. Inhalation exposure system, particle characterization, and effects following intratracheal instillation. Toxicol. Appl. Pharmacol (Manuscript submitted to this journal as a tandem paper to accompany this manuscript.).

Fubini B, Fenoglio I, Ceschino R, Ghiazza M, Martra G, Tomatis M, Borm P, Schins R, Bruch J, 2004 Relationship between the state of the surface of four commercial quartz flours and their biological activity in vitro and in vivo. Int. J. Hyg. Environ. Health 207, 89-104. [PubMed: 15031952]

Ghiazza M, Scherbart AM, Fenoglio I, Grendene F, Turci F, Martra G, Albrecht C, Schins RP, Fubini B, 2011 Surface iron inhibits quartz-induced cytotoxic and inflammatory responses in alveolar macrophages. Chem. Res. Toxicol 24, 99-110. [PubMed: 21171611]

Ghiazza M, Tomatis M, Doublier S, Grendene F, Gazzano E, Ghigo D, Fubini B, 2013 Carbon in intimate contact with quartz reduces the biological activity of crystalline silica dusts. Chem. Res. Toxicol 26, 46-54. [PubMed: 23082993]

Herberman RB, Ortaldo JR, 1981 Natural killer cells: their roles in defenses against disease. Science 214, 24-30. [PubMed: 7025208]

Jerne NK, Nordin AA, 1963 Plaque formation in agar by single antibody-producing cells. Science 140, 405.

Kim JH, Kim CS, Ignacio RM, Kim DH, Sajo ME, Maeng EH, Qi XF, Park SE, Kim YR, Kim MK, Lee KJ, Kim SK, 2014 Immunotoxicity of silicon dioxide nanoparticles with different sizes and electrostatic charge. Int. J. Nanomedicine 9 (Suppl. 2), 183-193.

Krajnak K, Russ KA, McKinney W, Waugh S, Zheng W, Kan H, Kashon ML, Johnson C, Cumpston J, Fedan JS, 2020 Biological effects of inhaled hydraulic fracturing sand dust. IV. Exposure to fracking sand dust results in changes in factors associated with cardiovascular dysfunction. Toxicol. Appl. Pharmacol (Manuscript submitted to this journal as a tandem paper to accompany this manuscript.).

Luster MI, Rosenthal GJ, 1993 Chemical agents and the immune response. Environ. Health Perspect 100, 219-226. [PubMed: 8354170] 
Maeda M, Nishimura Y, Kumagai N, Hayashi H, Hatayama T, Katoh M, Miyahara N, Yamamoto S, Hirastuka J, Otsuki T, 2010 Dysregulation of the immune system caused by silica and asbestos. J. Immunotoxicol 7, 268-278. [PubMed: 20849352]

Marrocco A, Meade BJ, Long CM, Lukomska E, Marshall NB, Anderson SE, 2015 Investigations into the immunotoxicity and allergic potential induced by topical application of nbutylbenzenesulfonamide (nbbs) in a murine model. J. Toxicol. Environ. Health Part A 78, 11221132.

McKinney W, Chen B, Schwegler-Berry D, Frazer DG, 2013 Computer-automated silica aerosol generator and animal inhalation exposure system. Inhal. Toxicol 25, 363-372. [PubMed: 23796015]

Moitra S, Puri R, Paul D, Huang YC, 2015 Global perspectives of emerging occupational and environmental lung diseases. Curr. Opin. Pulm. Med 21, 114-120. [PubMed: 25575364]

Mossman BT, Glenn RE, 2013 Bioreactivity of the crystalline silica polymorphs, quartz and cristobalite, and implications for occupational exposure limits (OELs). Crit. Rev. Toxicol 43, 632660. [PubMed: 23863112]

Nishijima N, Hirai T, Misato K, Aoyama M, Kuroda E, Ishii KJ, Higashisaka K, Yoshioka Y, Tsutsumi Y, 2017 Human scavenger receptor A1-mediated inflammatory response to silica particle exposure is size specific. Front. Immunol 8, 379. [PubMed: 28421077]

Olgun NS, Morris AM, Stefaniak AB, Bowers LN, Knepp AK, Duling MG, Mercer RR, Kashon ML, Fedan JS, Leonard SS, 2020 Biological effects of inhaled hydraulic fracturing sand dust. III. Cytotoxicity and pro-inflammatory responses caused in cultured murine macrophage cells. Toxicol. Appl. Pharmacol (Manuscript submitted to this journal as a tandem paper to accompany this manuscript.).

Pollard KM, 2016 Silica, silicosis, and autoimmunity. Front. Immunol 7, 97. [PubMed: 27014276]

Russ KA, Thompson JA, Reynolds JS, Mercer RR, Porter DW, McKinney W, Dey RD, Barger M, Cumpston J, Batchelor TP, Kashon ML, Kodali V, Sriram K, Fedan JS, 2020 Biological effects of inhaled hydraulic fracturing sand dust. IV. Pulmonary effects. Toxicol. Appl. Pharmacol (Manuscript submitted to this journal as a tandem paper to accompany this manuscript.).

Sager TM, Roberts JR, Umbright CM, Barger M, Kashon ML, Fedan JS, Joseph P, 2020 Biological effects of inhaled hydraulic fracturing sand dust. V. Pulmonary inflammatory, cytotoxic and oxidant effects. Toxicol. Appl. Pharmacol (Manuscript submitted to this journal as a tandem paper to accompany this manuscript.).

Sayan M, Mossman BT, 2016 The NLRP3 inflammasome in pathogenic particle and fibre-associated lung inflammation and diseases. Part Fibre Toxicol 13, 51. [PubMed: 27650313]

Sriram K, Lin GX, Jefferson AM, McKinney W, Jackson MC, Cumpston A, Cumpston JL, Cumpston JB, Leonard HD, Kashon ML, Fedan JS, 2020 Biological effects of inhaled hydraulic fracturing sand dust. VII. Neuroinflammation and altered synaptic protein expression. Toxicol. Appl. Pharmacol (Manuscript submitted to this journal as a tandem paper to accompany this manuscript.).

Zelikoff JT, Schermerhorn KR, Fang K, Cohen MD, Schlesinger RB, 2002 A role for associated transition metals in the immunotoxicity of inhaled ambient particulate matter. Environ. Health Perspect 110 (Suppl. 5), 871-875. 

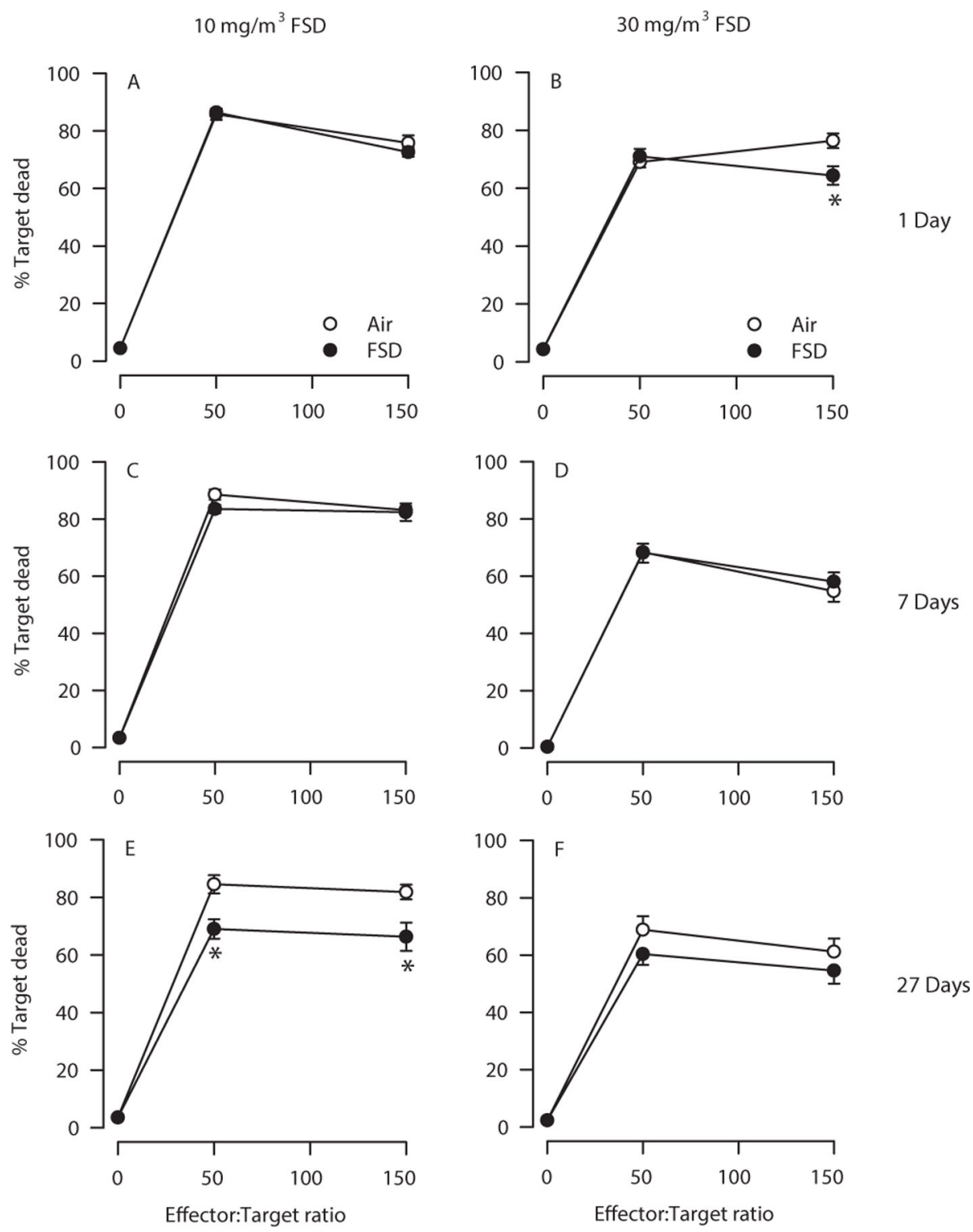

Fig. 1.

Inhalation exposure to FSD 8 suppresses spleen NK cell activity. (FSD 8 is abbreviated as FSD in the figures.) NK cell activity in splenocytes was evaluated after exposure to 10 or 30 $\mathrm{mg} / \mathrm{m}^{3}$ of FSD 8 . NK cell percent killing is illustrated at $1 \mathrm{~d}(\mathrm{~A}, \mathrm{~B}), 7 \mathrm{~d}(\mathrm{C}, \mathrm{D})$ and $27 \mathrm{~d}(\mathrm{E}$, F) post-exposure. $n=4$ animals in each group. $* P<0.01$ vs. air control at indicated effector:target ratio. 
$\mathrm{PFC} / 10{ }^{6}$ Spleen cells
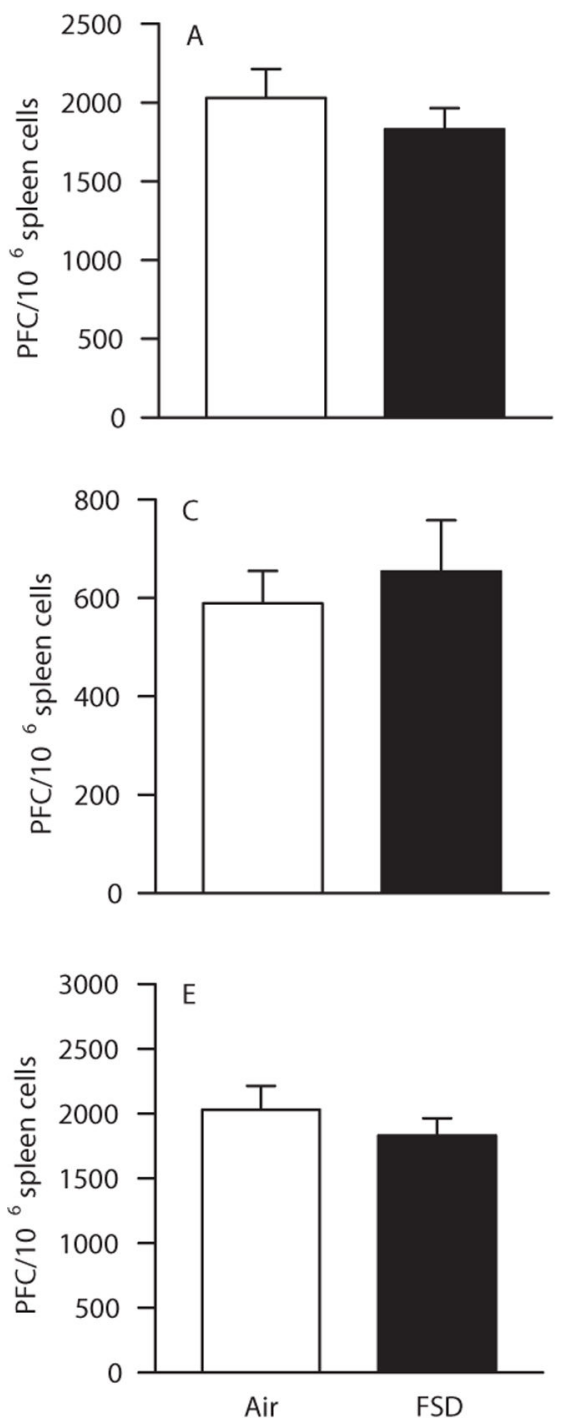

PFC/Spleen
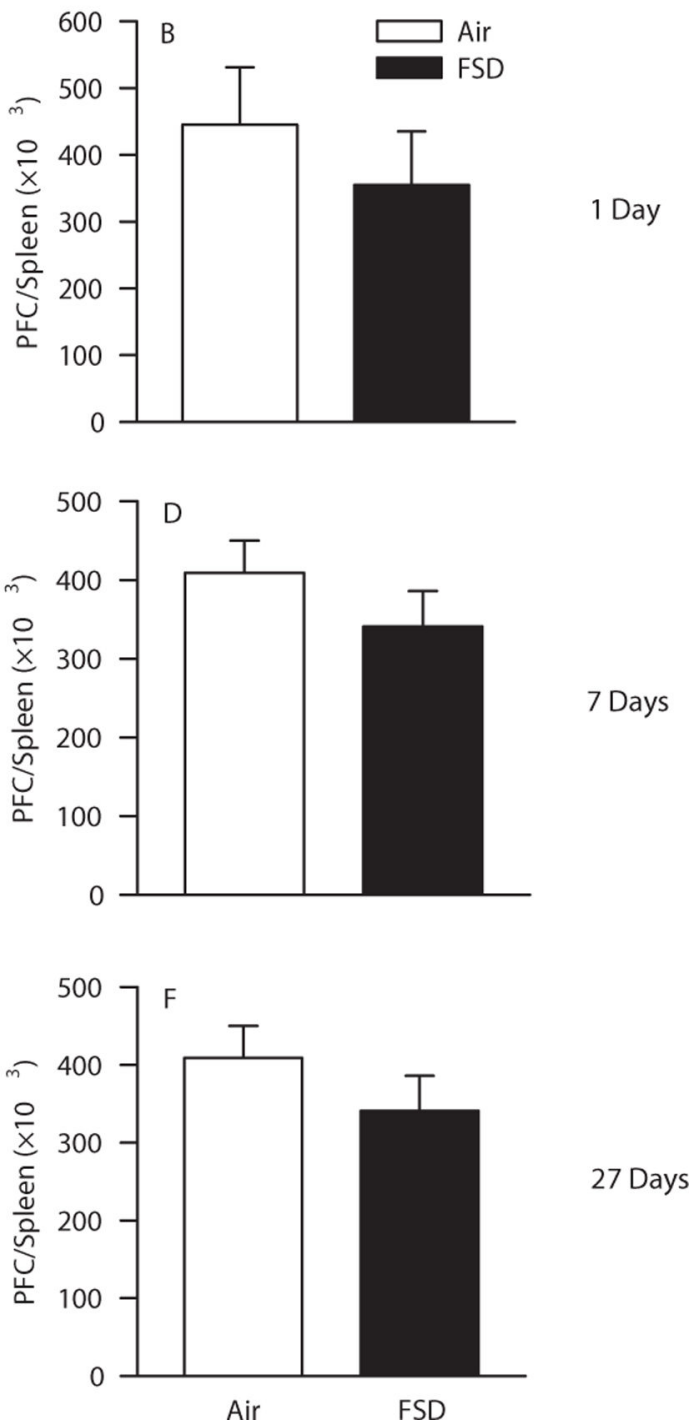

Fig. 2.

Inhalation exposure to $10 \mathrm{mg} / \mathrm{m}^{3} \mathrm{FSD} 8$ does not suppress the spleen IgM response to SRBC.

The spleen IgM response to SRBC was evaluated after exposure to $10 \mathrm{mg} / \mathrm{m}^{3}$ of FSD 8 . The IgM response to $\mathrm{SRBC} / 10^{6}$ splenocytes and $\mathrm{IgM}$ response to $\mathrm{SRBC} /$ spleen is illustrated at 1 $\mathrm{d}(\mathrm{A}$ and $\mathrm{B}), 7 \mathrm{~d}(\mathrm{C}$ and $\mathrm{D})$ and $27 \mathrm{~d}(\mathrm{E}$ and $\mathrm{F})$ post exposure. $n=8$ animals in each group. 

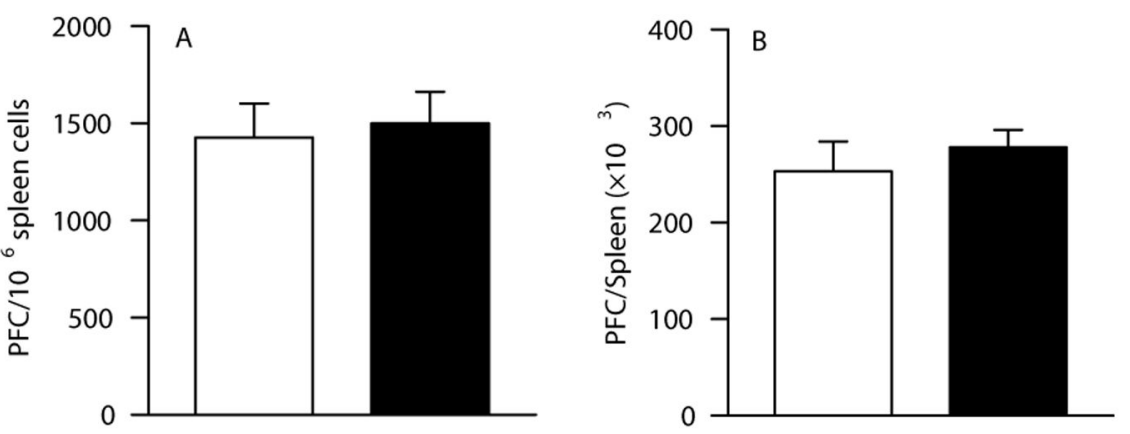

1 Day
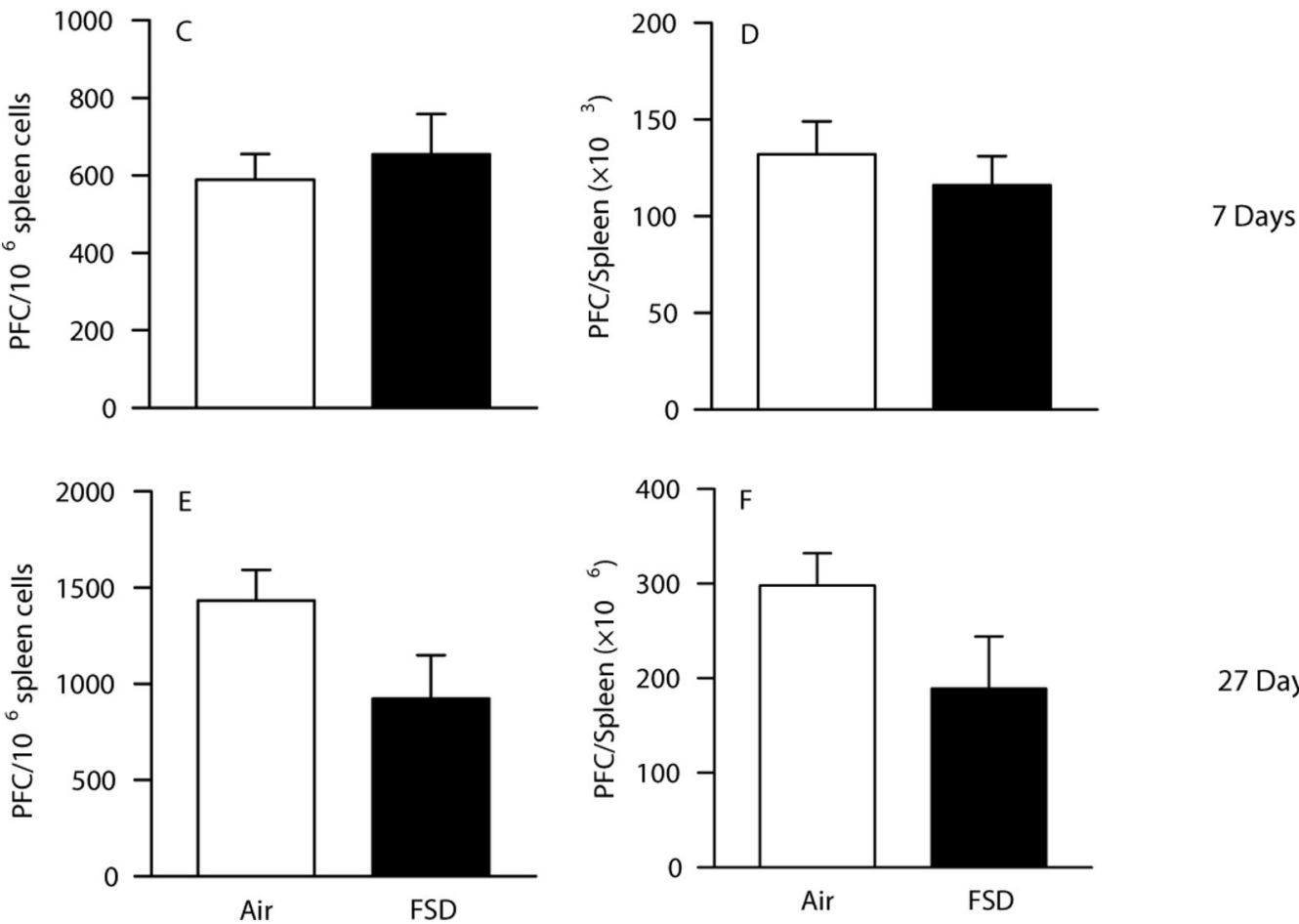

Fig. 3.

Inhalation exposure to $30 \mathrm{mg} / \mathrm{m}^{3}$ FSD 8 does not suppress the spleen IgM response to SRBC.

The spleen IgM response to sheep red blood cells (SRBC) was evaluated after exposure to $30 \mathrm{mg} / \mathrm{m}^{3}$ of FSD 8 . The IgM response to SRBC/10 6 splenocytes and IgM response to $\mathrm{SRBC} /$ spleen is illustrated at 1 day (A and B), $7 \mathrm{~d}(\mathrm{C}$ and $\mathrm{D})$ and $27 \mathrm{~d}$ (E and F) postexposure. $n=8$ animals in each group. 


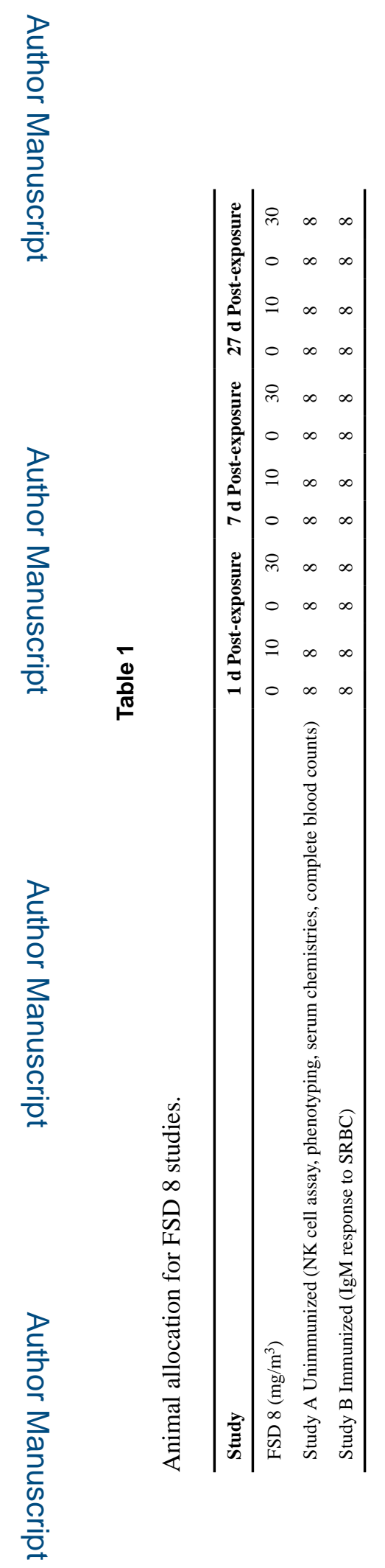

Toxicol Appl Pharmacol. Author manuscript; available in PMC 2021 January 09. 


\section{을 \\ }

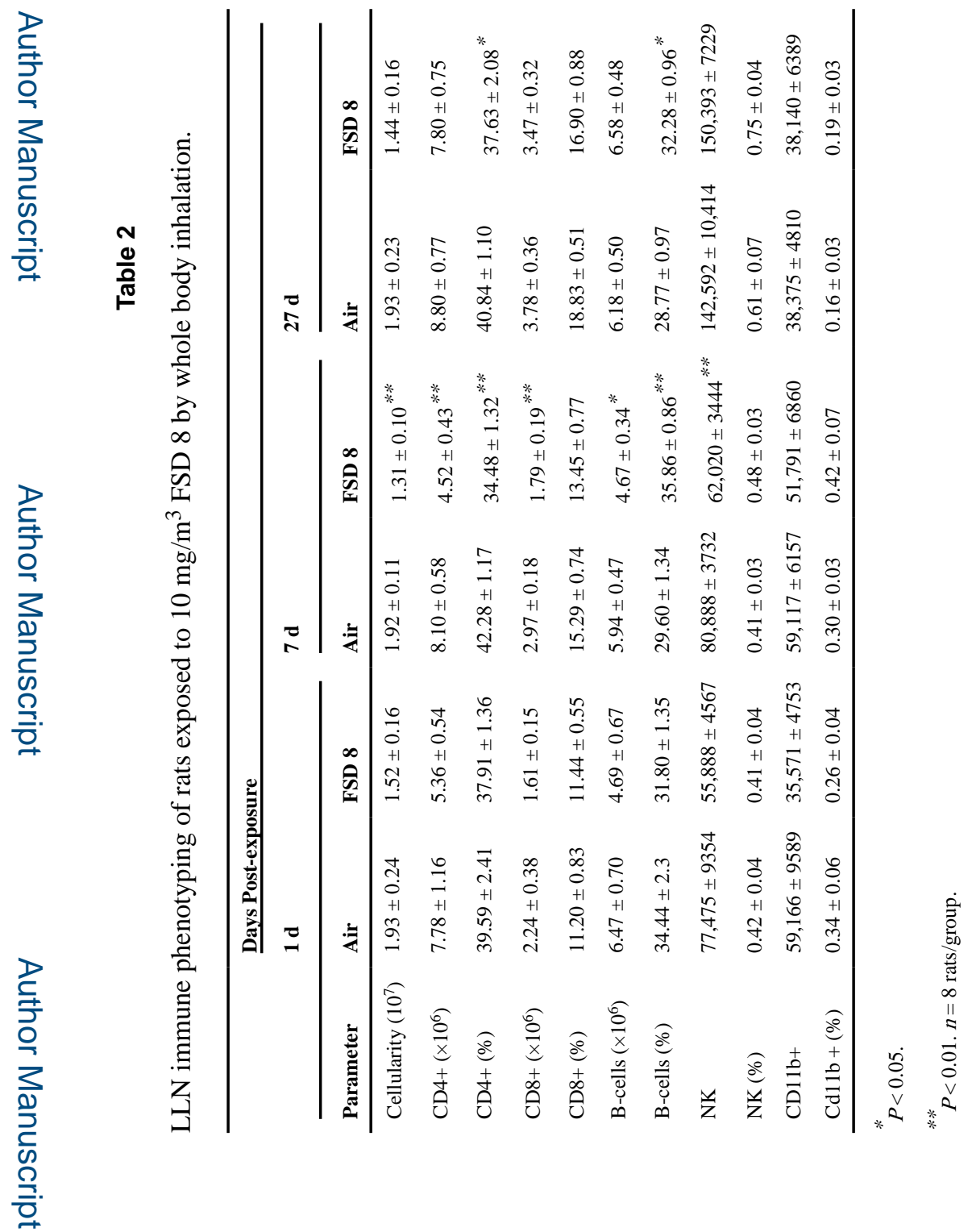

Toxicol Appl Pharmacol. Author manuscript; available in PMC 2021 January 09. 


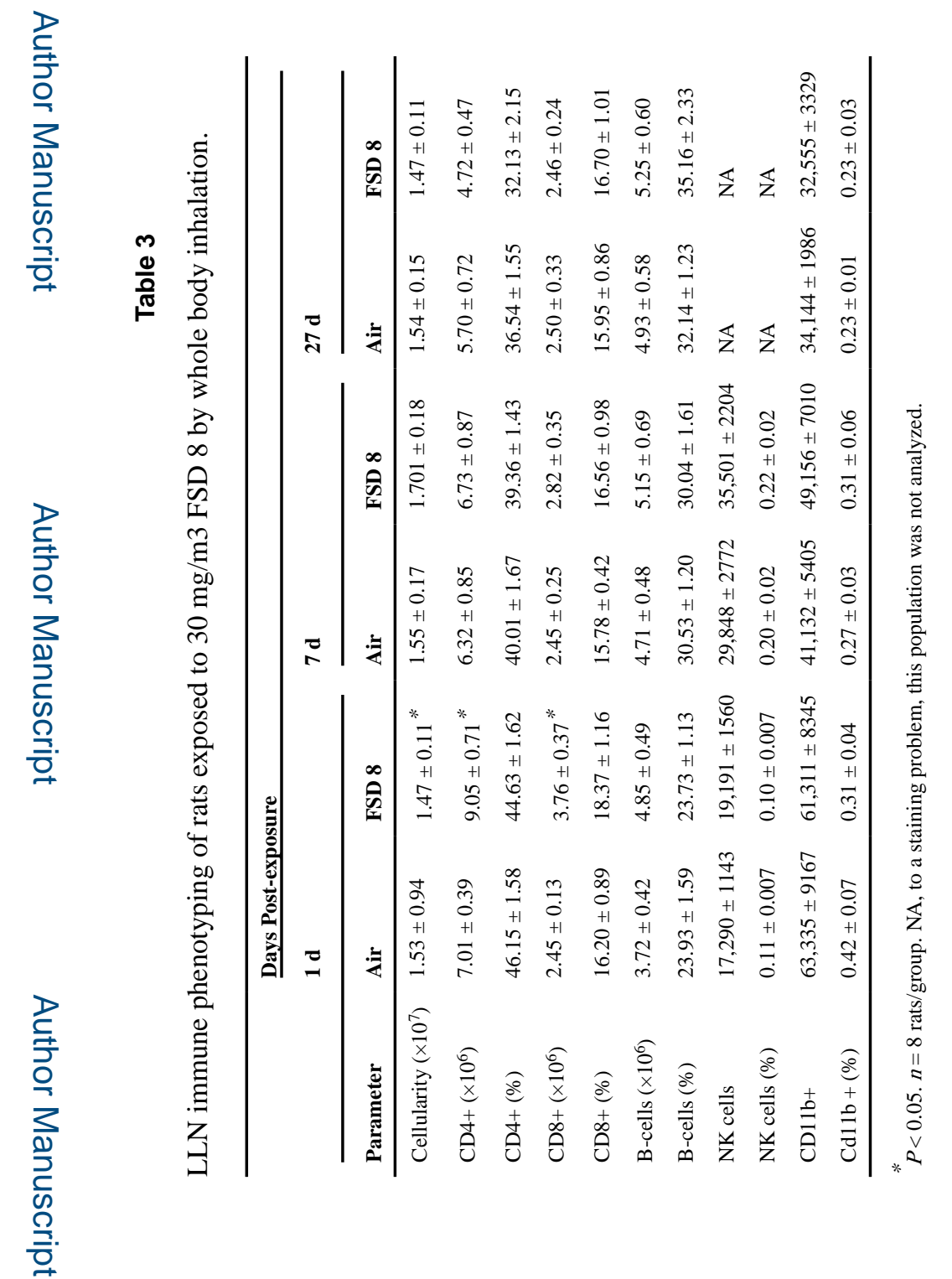

Toxicol Appl Pharmacol. Author manuscript; available in PMC 2021 January 09. 


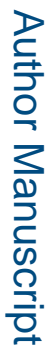

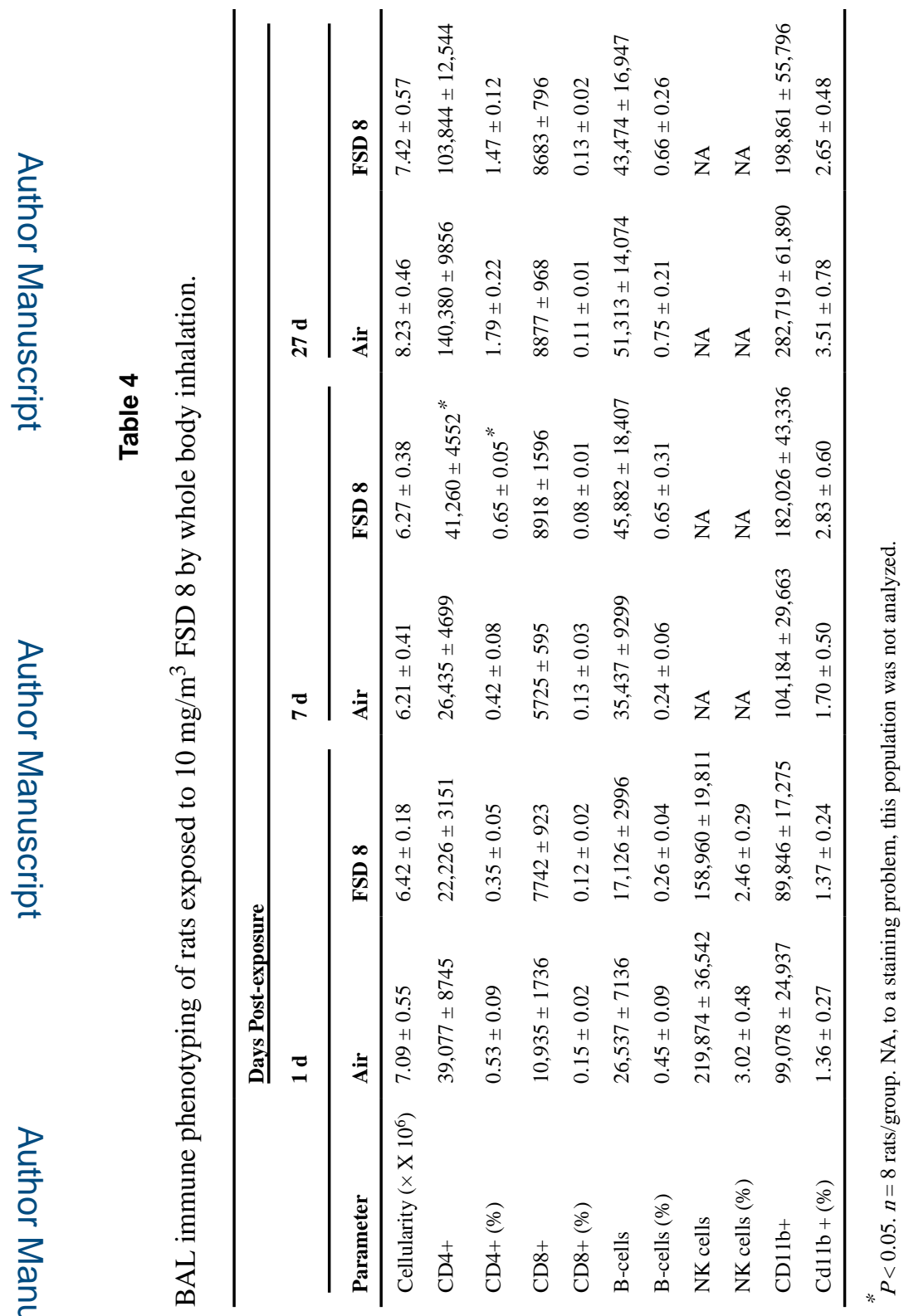




\section{을 \\ 길}

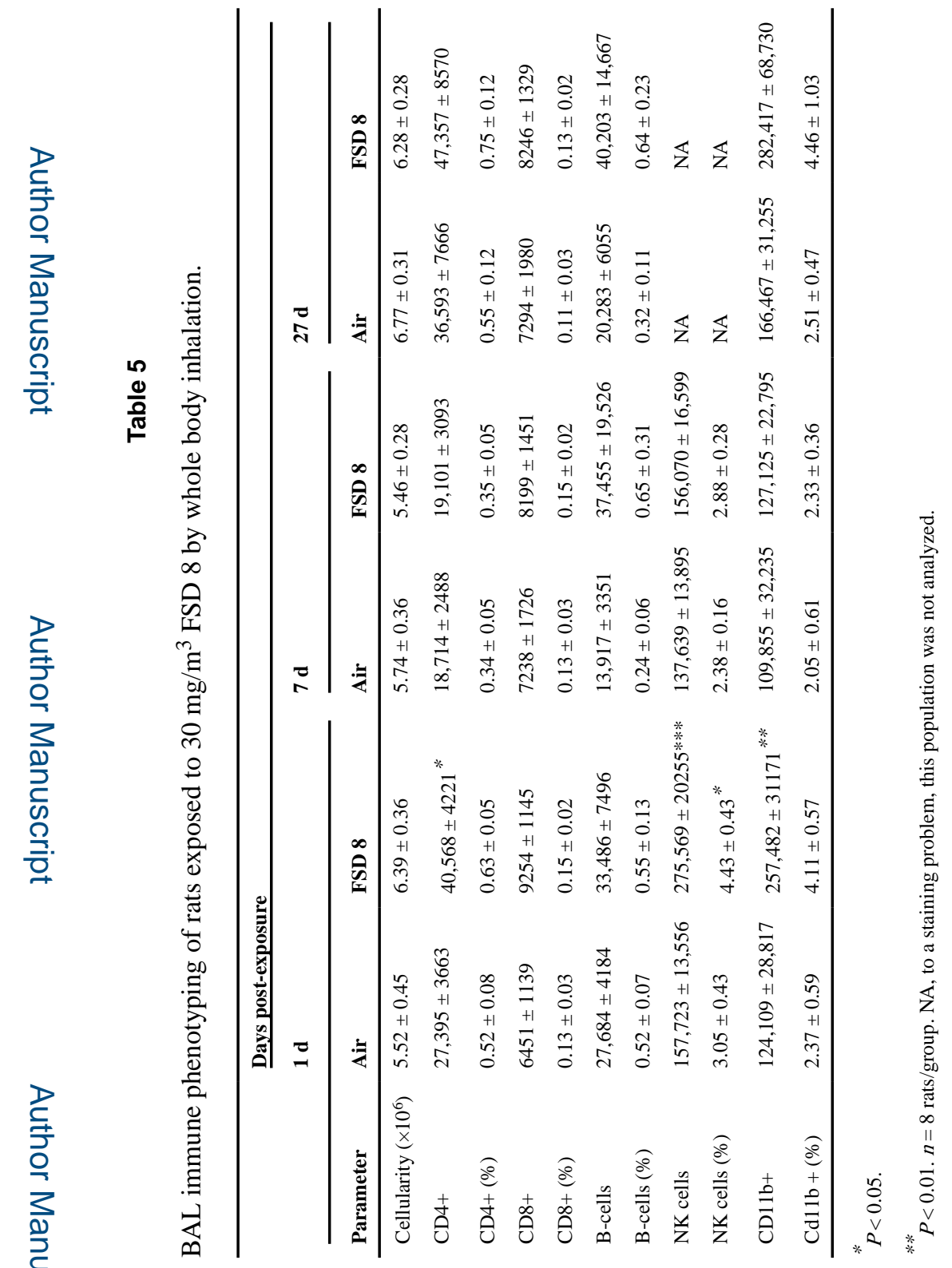

Toxicol Appl Pharmacol. Author manuscript; available in PMC 2021 January 09. 